\title{
Oospores of Phytophthora infestans in soil provide an important new source of primary inoculum in Finland
}

\author{
Ari Lehtinen and Asko Hannukkala \\ MTT Agrifood Research Finland, Plant Production Research, Plant Protection, FI- 31600 Jokioinen, Finland, \\ e-mail: ari.lehtinen@mtt.fi and asko.hannukkala@mtt.fi
}

\begin{abstract}
There have been numerous indications since the 1990s that oospore-derived primary infections play an increasing role in the epidemiology of potato late blight. The aim of this study was to verify that oosporederived epidemics actually occur in Finland. For this purpose, 20 suspected foci of oospore-derived potato late blight were scouted in 2000-2002. All of these were located in fields in which late blight had been observed in at least one of the four previous years. Primary symptoms in these foci occurred always on the lowest leaves near or touching the ground. Leaflets typically showing numerous primary infections or lesions were in direct contact with the soil. In the former, oospores were observed after incubation. Soil samples from two experimental fields, marked by severe epidemics in most years during the last decade, caused infections in a bioassay. Both mating types were on every occasion present in groups of single lesion isolates collected from foci and the bioassay. Oospores survived over the winter, as shown by soil samples taken during the spring that infected potato leaflets in the bioassay. The results presented indicate that oospore-derived epidemics occur in Finland. This paper also discusses the role of oospores in causing blight epidemics in Finland compared to more southern countries.
\end{abstract}

Key words: potatoes, Solanum tuberosum, potato late blight, Phytophthora infestans, epidemiology, oospores, mating type, sexual reproduction, soil borne inoculum

\section{Introduction}

Potato late blight, which is caused by the oomycete Phytophthora infestans (Mont.) de Bary, is a worldwide devastating disease of potatoes. The pathogen is heterothallic, and its two mating types are named A1 and A2. Before the late 1970s, only the A1 mating type of $P$. infestans was present outside Mexico. In the early 1980s, a new potato late blight population migrated from Mexico to Europe and replaced the old asexual population (Fry and Goodwin 1997). The first indication of the change was the appearance of the A 2 mating type of $P$. in- 
Lehtinen, A. \& Hannukkala, A. Oospore-derived potato late blight

festans in Europe (Hohl and Iselin 1984). The presence of both mating types in a population enables the sexual reproduction of $P$. infestans, resulting in the formation of oospores (Gallegly 1968). Monitoring of the occurrence of the A2 mating type in Finland was started in 1992 when it proved to be present in a very low proportion in the potato late blight population. Unfortunately, no older isolates of the pathogen are available, so the exact time of appearance of A2 remains unsolved (Hermansen et al. 2000).

Asexually reproducing $P$. infestans is able to overwinter only as mycelium in surviving tubers in storage or cull piles or in ones left in the soil during harvest that then produce volunteer plants in the next season (Zwankhuizen and Zadoks 2002). In the northern climate, the cold winters limit the survival of the asexual stage of $P$. infestans in infected tubers in frozen soil. Therefore, the build-up of blight epidemics due to asexual sources of primary inoculum was usually delayed until the end of August (Mäkelä 1966, Seppänen 1971). The oospores formed in a sexually reproducing population provide a new serious overwintering source of primary inoculum independent of the survival of the tubers during cold winters. The oospores are known to be very tolerant of low temperatures (Drenth et al. 1995, Fay and Fry 1997).

There is convincing evidence that oospores resulting from sexual reproduction are formed in potato crops under field conditions throughout Northern Europe (Drenth et al. 1995, Andersson et al. 1998). Less clear is still the relative importance of oospores as a source of primary inoculum. Oospores have been shown to persist in soil for 3-4 years in the Netherlands (Turkensteen et al. 2000). It has also been shown that oospores can infect potatoes at least under greenhouse conditions (Drenth et al. 1995, Strömberg et al. 1999). In Sweden, suspected oospore-derived foci have been reported in a field trial where a heavy attack of potato late blight was present in the previous potato crop (Andersson et al. 1998). The presence of both mating types and oospores in infected leaflets in the foci supports the hypothesis that oospores were responsible for the outbreak of the epidemic.

The aim of the present study was to verify that oospore-derived epidemics actually occur in Fin- land. Circumstantial indications of suspected oospore-derived epidemics were gathered during late blight surveys in the 1990s (Drenth et al. 1995, Andersson et al. 1998, Zwankhuizen and Zadoks 2002). In the present study, an epidemic was defined to be oospore derived if the following four conditions were fulfilled:

1) Foci appearing relatively early in a potato stand in a field where late blight attacks had occurred in at least one of the previous four years (Turkensteen et al. 2000).

2) Primary lesions emerging from leaf edges touching the soil or from stems (Andrivon 1995, Fernández-Pavia et al. 2001).

3) Both mating types present in the early stage of the epidemic, as each oospore in the progeny has a chance to inherit the A1 or A2 trait from its parents (Gallegly 1968, Drenth et al. 1995, Judelson et al. 1995).

4) Soil collected from the suspected oospore-derived foci able to infect detached potato leaves in bioassay (Drenth et al. 1995).

\section{Material and methods}

\section{A field survey}

A field survey was carried out in 2000-2002 to find potential oospore-derived early infections initiating late blight epidemics. The monitoring concentrated on experimental trial sites of MTT Agrifood Research Finland in Jokioinen and of the Potato Research Institute in Lammi. In addition, about 30 farmers producing early potatoes under plastic or fibre cover on the south-western coast of Finland were reviewed annually for the occurrence of early attacks of late blight.

\section{Primary lesions and oospore formation}

When a blight focus was found, observations were made on the development of symptoms in the lowest leaves touching the ground. Leaves with mosaic-like symptoms were collected and incubated 
Vol. 13 (2004): 399-410.

to study the potential oospore production on them. Leaf discs $1.5 \mathrm{~cm}$ in diameter were cut with a cork borer and incubated for 10 to 14 days in water in Petri dishes at $15^{\circ} \mathrm{C}$ with relative humidity $(\mathrm{RH})$ above $90 \%$. After incubation, the leaf discs were transferred to a glass slide and flattened under a cover glass. The occurrence of oospores of $P$. infestans was verified using a light microscope.

In 2000, naturally infected stems were collected from Jokioinen and Nummi-Pusula and examined for the occurrence of oospores. Twenty plants were sampled from late blight foci from both fields. The stems were cut into lengths of $5 \mathrm{~cm}$ in the laboratory and boiled in $96 \%$ ethanol for 20 minutes, then bleached in $1 \% \mathrm{NaClO}$ for 10 minutes. Longitudinal slices of stems were mounted on glass slides with the help of a drop of lactic acid, and the presence of oospores was checked with a light microscope.

\section{PCR diagnostics}

When primary symptoms were found on the stems, the whole plant was collected and stored in a freezer to verify whether the infection originated from the mother tuber. Samples were prepared from the mother tuber, daughter tubers, stem in the middle with symptoms, and lower leaves touching the ground by forcing the sap out of plant pieces with a press (Elektrowerk, Behncke \& Co, Hannover, Germany). A 50- $\mu$ l aliquot of the sap was used for DNA extraction. DNA was extracted by using a DNeasy Plant Mini Kit (Qiagen, Hilden, Germany). The extracted DNA $(0.5 \mu \mathrm{l})$ was amplified by a nested polymerase chain reaction (PCR) in reaction conditions recommended by the manufacturer of Dynazyme DNA polymerase (Finnzymes, Espoo, Finland). The specific primer pairs used were O8-1/O8-4 and O8-3/O8-4. The result was a 258bp DNA fragment that is part of the O8 DNA family (Judelson and Tooley 2000). The temperatures and times in PCR were as described by Judelson and Tooley (2000). The PCR products $(8 \mu \mathrm{l})$ were analysed by electrophoresis through a $0.8 \%$-agarose gel containing $0.5 \mu \mathrm{g} \mathrm{ml}^{-1}$ of ethidium bromide and visualised by UV transillumination using a
Chemilmager 4000 (Alpha Innotech Corporation, San Leandro, CA, USA).

\section{Mating type analysis}

Soil samples and a number of leaflets with a single blight lesion were collected from suspected oospore-derived foci at the onset of the epidemic. The rationale for the early sampling was to verify whether the mating type ratio of isolates present in the early focus was in the expected range of a sexually reproducing population. Mating type data from earlier surveys was analysed to compare the mating type ratio between suspected oospore-derived foci and air-borne epidemics. Isolates belonging to air-borne epidemics were selected by including only fields in which at least 10 isolates were collected. Surveys were carried out and isolates were collected and tested for mating type during the years 1994, 1997, 1998, 1999, and 2000.

To determine the mating type, the leaflets with a single lesion were incubated in Petri dishes on moist filter paper for 2-5 days in a greenhouse at $15^{\circ} \mathrm{C}$ at $>90 \% \mathrm{RH}$ to enhance sporulation. Some of the isolates were transferred to fresh potato leaflets to increase the inoculum for the mating type assay. The mating type of the isolates was determined after incubation by pairings with known A1 and A2 isolates. These tester isolates were 90209 (A1) and 88055 (A2) from the Netherlands, obtained from Cyanamid Forschung GmbH, Germany, and 18 (A1) and 90 (A2) provided by Björn Anderson and Magnus Sandström, SLU, Swedish University of Agricultural Sciences. Mating type tests were done on floating leaf discs, which has proved to be a rapid method (Hermansen et al. 2000). Most of the isolates were also isolated as pure cultures on rye agar and characterised for mating type on rye agar (Gallegly and Galindo 1958).

\section{Soil infectivity analysis}

Four soil samples of 10 litres were collected in October 2000 from a field in Jokioinen, where po- 
tatoes had been grown in continuous monoculture since 1990. The potato crop on this particular field had been heavily infected by late blight every year except in 1995 and 1999.

The soil samples were stored in an unheated warehouse subjected to temperatures fluctuating between +5 and $-20^{\circ} \mathrm{C}$. The samples were moved to room temperature $\left(19-21^{\circ} \mathrm{C}\right)$ in February 2001. Five soil samples were collected from the same field on 5 May 2001 before the potato crop was planted, although not exactly from the same sampling sites as in the previous autumn. Soil samples of 1-2 litres in volume were also acquired from 15 suspected oospore-derived blight foci in eight commercial production fields located in different parts of Finland. The samples were stored at 8$10^{\circ} \mathrm{C}$ until testing.

Prior to testing, the soil samples were made as homogeneous as possible by mixing them by hand in containers 10 times larger than the sample volume. The infectivity of the soil samples collected in autumn 2000 in Jokioinen was tested in bioassays carried out from February to June 2001. The remaining soil samples were tested from January to March 2002.

The spore baiting bioassay was carried out following a modification of the procedure described by Drenth et al. (1995). Subsamples of one litre in size were placed in plastic containers $(37 \times 28 \times 11 \mathrm{~cm})$. The soil layer was covered with tap water up to a height of at most $1 \mathrm{~cm}$. After the water was added, samples were kept overnight in a freezer. The next day, the samples were transferred from the freezer to a greenhouse. The containers were incubated under a transparent plastic lid at $15^{\circ} \mathrm{C}$ in natural daylight. One day later, leaflets were placed abaxial side up on the water. As a consequence of the amount of water used, only a very small proportion of the leaflets were in direct contact with the soil. Except at weekends, leaflets were checked daily for symptoms. Leaflets with sporulating lesions were immediately removed from the containers, and the sporangia were verified by microscope as $P$. infestans. After two weeks of incubation, symptomless leaflets were removed and replaced by new leaflets.

\section{Results}

\section{The field survey and primary lesions}

The field survey was arranged to verify that oospore-derived epidemics actually occur in Finland. The aim of the survey was to find potato late blight foci appearing relatively early in potato stands in fields where late blight attacks had occurred in at least one of the preceding four years (Turkensteen et al. 2000). In addition, the goal was to find primary lesions that emerged from leaf edges touching the soil or from stems (Andrivon 1995, Fernández-Pavia et al. 2001). A total of 20 suspected oospore-derived late blight foci were studied in the years 2000, 2001, and 2002 (Table 1). Eight of them were detected in an early stage, thus providing primary lesions for observation. The first lesions appeared on the leaves near or touching the soil, and they were marked by mosaic-like discolorations indicating numerous simultaneous infection sites per leaf (Fig. 1), or they originated from the edge of the leaflet in contact with the soil (Fig. 2). Sporulation was very weak in the leaves with mosaic-like symptoms and almost invisible without magnification. The leaves died within 2-4 days.

In Lammi, the initial blight symptoms appeared in 2001 on three neighbouring stems in one row. Secondary lesions on leaves were observed on plants around the stem-infected plants. Tuberborne inoculum was excluded since no late blight symptoms were observed on mother tubers and since the tubers did not contain detectable levels of P. infestans DNA (Fig. 3). It is also unlikely that only three neighbouring plants would have been infected by air-borne inoculum. Thus, regarding primary symptom development, all eight described foci could be considered as oospore-derived foci.

\section{Formation of oospores in the field}

A prerequisite of oospore-derived infections is the formation of oospores in potato fields. Therefore, leaflets showing multiple lesions were collected 
Vol. 13 (2004): 399-410.

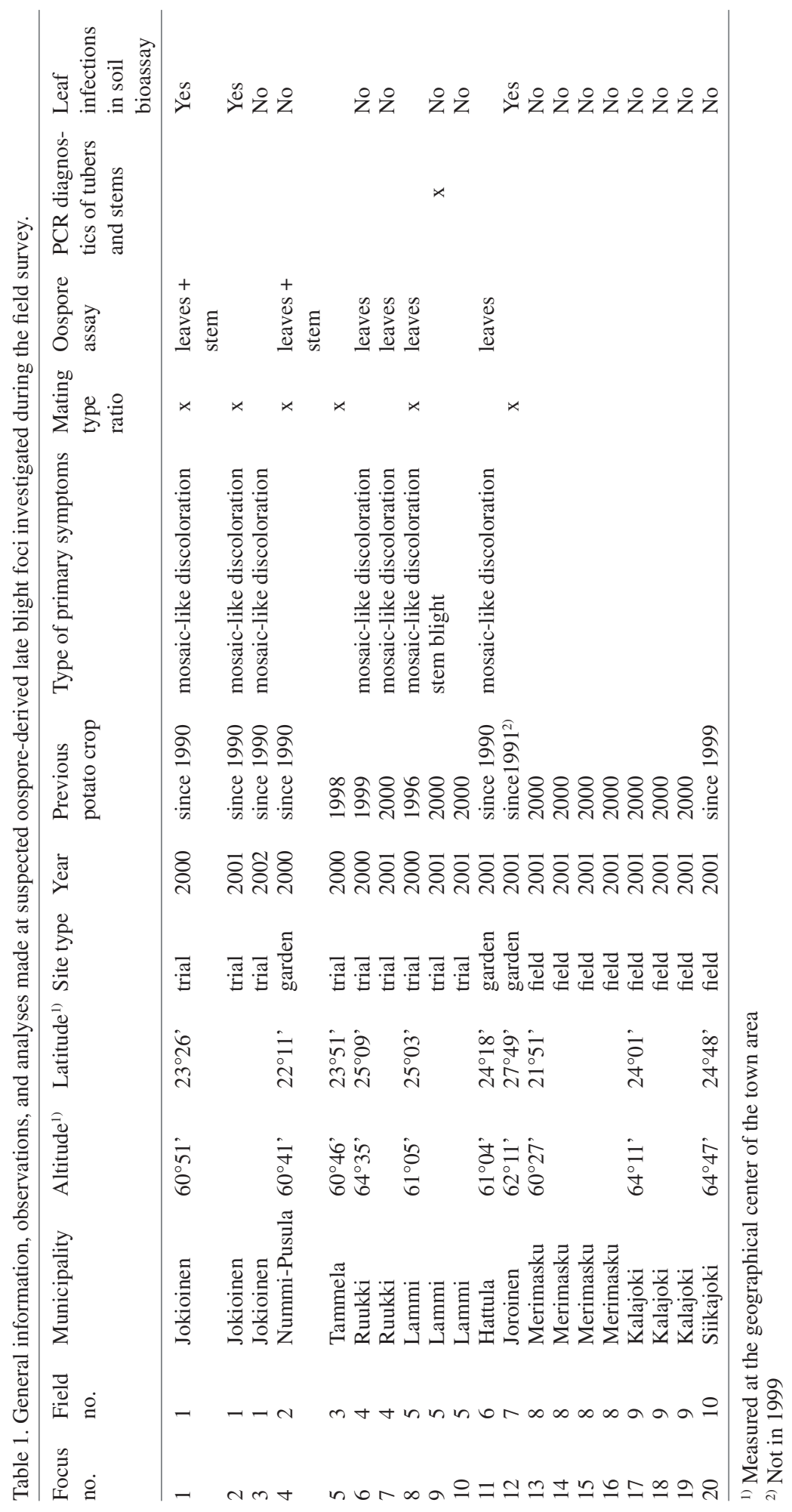




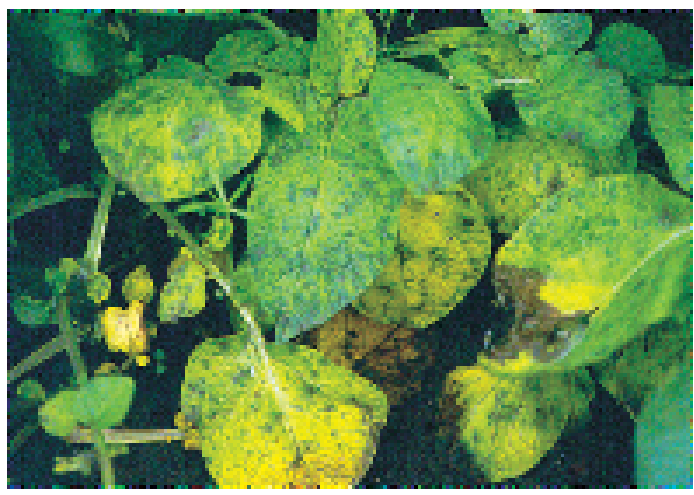

Fig. 1. Numerous small mosaic-like lesions caused by $P$. infestans in a single leaf.

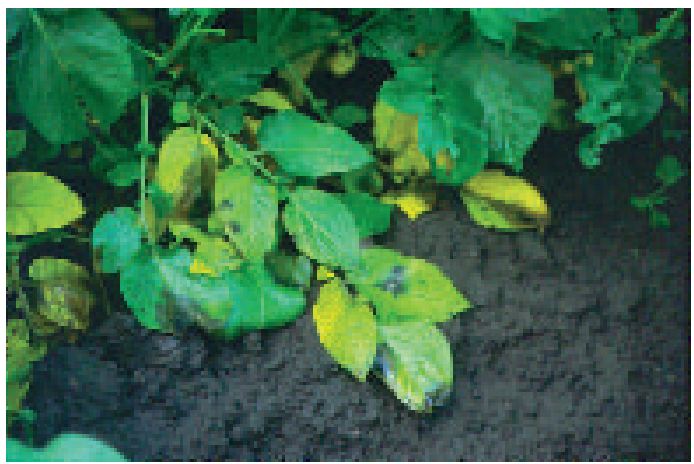

Fig. 2. A lesion starting from the edge of a leaflet in direct contact with the soil.

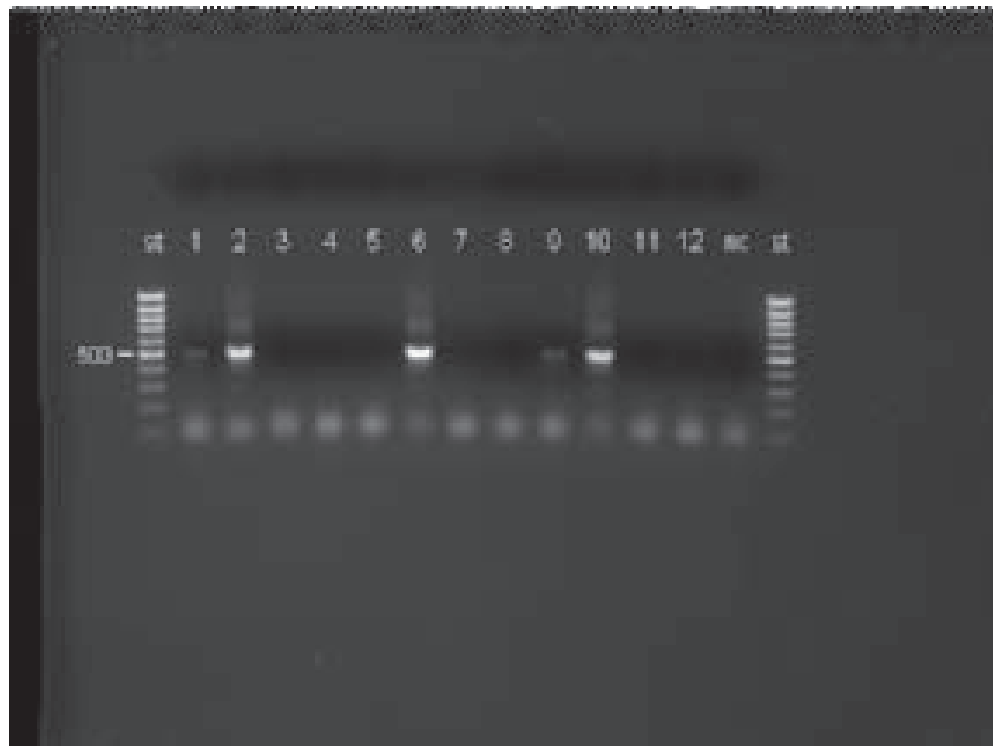

Fig. 3. Gel electrophoresis of amplification products after polymerase chain reaction, with DNA extracted from different parts of the three potato plants showing stem blight symptoms. St: 100 bp DNA ladder; lanes 1-4: plant 1; lanes 5-8: plant 2; lanes 9-12: plant 3: lanes 1, 5, and 9: lower leaf; lanes 2, 6, and 10: stem from middle of the plant; lanes 3, 7, and 11: seed potato; lanes 4, 8, and 12: daughter tuber; nc: negative control. from six suspected oospore-derived foci and stems from the foci at Jokioinen and Nummi-Pusula (Table 1). Leaf discs derived from all of the six foci formed oospores in Petri dishes after incubation (Fig. 4). Oospores were also observed in the stems collected from Jokioinen, but not in those from Nummi-Pusula. Since the stems were analysed right after sampling, the formation of oospores is possible under favourable weather conditions in Finnish potato fields.

\section{Mating type ratio and oospores in foci}

Oospores occur in batches in the soil since a single leaflet can contain thousands of oospores (Drenth et al. 1995). Thus, it is probable that multiple oospores will germinate under favourable conditions producing a mixture of $\mathrm{A} 1$ and $\mathrm{A} 2$ zoospores, which result in the formation of oospores in foci. The presence of both mating types in suspected oospore-derived foci and air-borne epidemics was 
Vol. 13 (2004): 399-410.

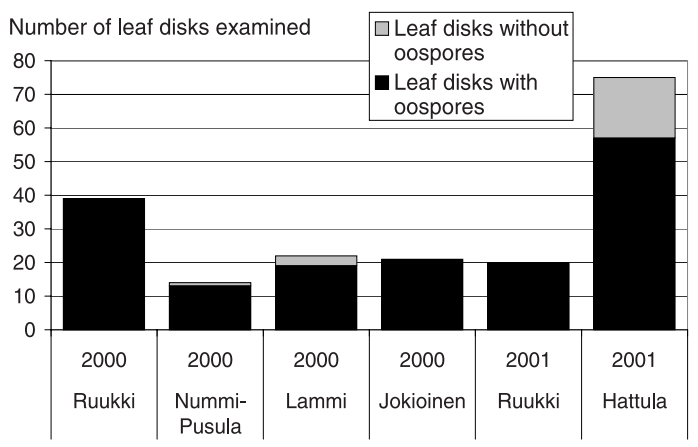

Fig. 4. Oospores of $P$. infestans inside a potato leaf disc detected after incubation in the laboratory in different locations and years.

studied to test if the mating type ratio or the presence of the oospores can support the hypothesis of the foci being oospore-derived.

Both mating types were always present in populations of single lesion isolates collected from suspected oospore-derived foci or from bioassay (Fig. 5 and 6). In addition, every sampled focus having primary infected leaflets and showing multiple lesions produced oospores in leaf discs derived from these leafs, which indicates the presence of both mating types (Fig. 4). In contrast, $37 \%$ of fields with air-borne epidemics had only one mating type present, and $37 \%$ of the remaining fields had a frequency of at least $80 \%$ of the dominating mating type (Fig. 7). Thus, the occurrence of both mating types was substantially more common in suspected oospore-derived populations.

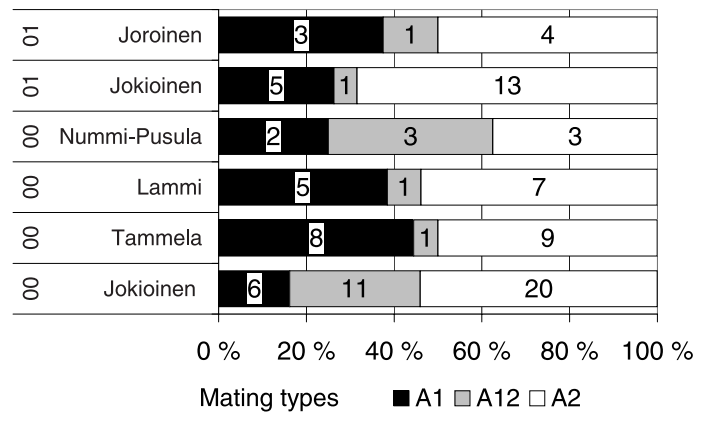

Fig. 5. Mating types of isolates collected from different suspected oospore-derived foci. Number of isolates studied indicated within bars.

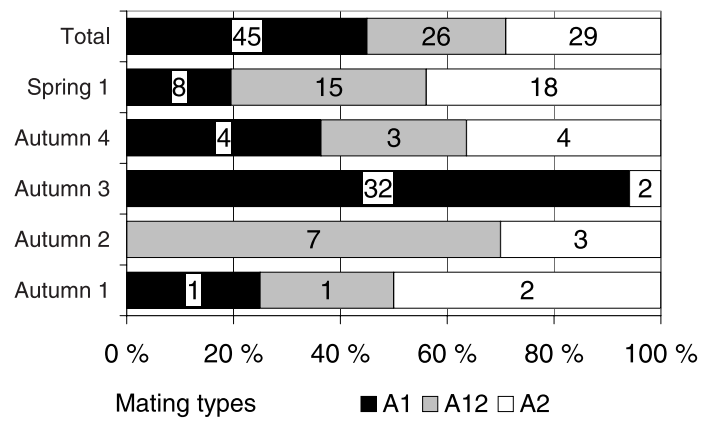

Fig. 6. Mating types of isolates from four soil samples collected in Jokioinen in autumn 2000 (autumn 1-4) and from one in spring 2001 (spring 1). Number of isolates studied indicated within bars.

\section{Oospore occurrence in soil}

Soil samples were collected from suspected oospore-derived disease foci to gather indirect evidence for oospore-derived infections. Only three soil samples taken from the 16 distinct foci were infective in the bioassay. The first symptoms were observed 5-26 days after starting a test. In Jokioinen, soil samples collected from the same field in both autumn 2000 and spring 2001 resulted in sporulating late blight lesions in the bioassay (Table 1), indicating that oospores are able to survive in the soil to the next growing season. However, despite careful mixing of the soil samples, considerable variation in the amount of infection was observed between subsamples (data not shown). Thus, the bioassay and our sampling scheme may not have been sensitive enough to detect an inoculum capable of causing infections.

\section{Discussion}

It is very difficult to prove directly that oospores caused an infection observed in the field. Therefore, we decided to investigate if the prerequisites for oospore-derived infections are fulfilled in Finland. In addition, suspected oospore-derived late blight foci were investigated to verify if the symptoms, mating type ratio, and the presence of oospores in 


\section{AGRICULTURAL AND FOOD SCIENCE}

Lehtinen, A. \& Hannukkala, A. Oospore-derived potato late blight

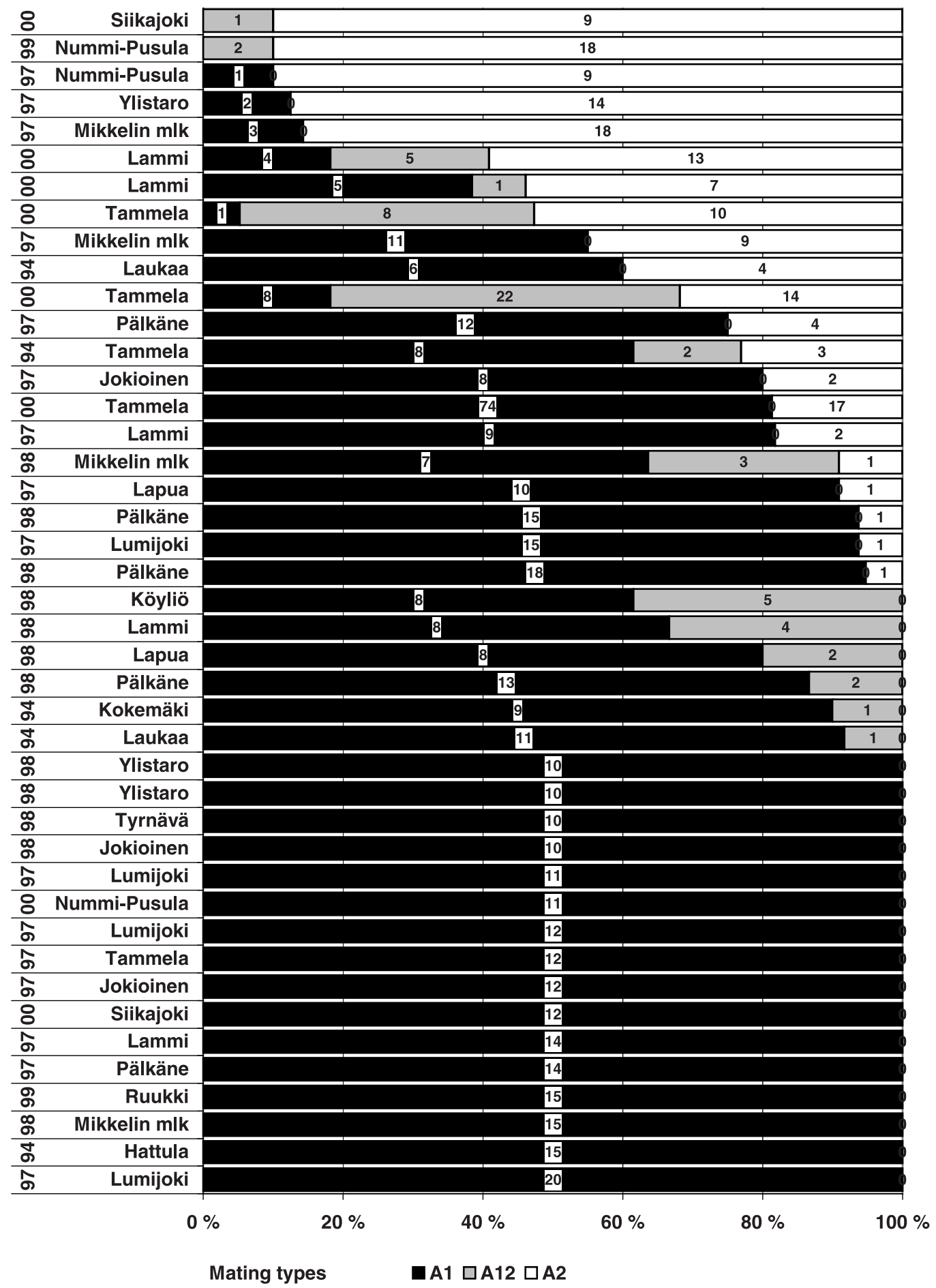

Fig. 7. Distribution of mating types in air-borne epidemics observed at different locations during the years 1994, 1997, 1998, 1999, and 2000. Number of isolates studied indicated within bars. 
Vol. 13 (2004): 399-410.

soil support the hypothesis of an oospore-derived infection. There is also a discussion of the role of oospores in causing blight epidemics in Finland compared to more southern countries.

\section{Prerequisites for oospore-derived infections}

Prerequisites for oospore-derived infections are that oospores be formed in potato fields and that they survive until the next growing season in the soil under natural weather conditions. It has already been shown by Hermansen et al. (2000) that both mating types are present in Finland. After incubation in moist conditions, oospores were observed in leaves from all studied foci, and they were observed even without incubation in stems collected from Jokioinen. Thus, P. infestans can produce oospores in Finnish potato fields. Soil samples taken in May 2001 from the same field in Jokioinen showed that oospores survive in the soil until the next growing season. Oospores have also been shown to overwinter in the Netherlands (Drenth et al. 1995, Turkensteen et al. 2000) and Canada (Medina and Platt 1999).

\section{Primary lesions}

The first lesions were typically observed on the lowest leaves as mosaic-like discolorations or lesions in direct contact with the soil. Oospores are an obvious explanation for lesions starting from leaf edges touching the soil. It is also difficult to explain how numerous primary lesions on leaves in close or direct contact with the soil could be initiated by an air-borne inoculum since the upper leaves in the crop were symptomless.

Germinating oospores produce germ tubes with terminal sporangia that can germinate directly or indirectly as asexual sporangia (Smoot et al. 1958, Erwin and Ribeiro 1996, p. 53). Since the oospores in the soil occur in patches where leaflets containing oospores have decomposed (Drenth et al. 1995), it is plausible that some oospores are splashed by rain onto leaflets, where they germinate, produce zoospores by indirect germination of sporangia, and infect the leaflets. Numerous infections in a single leaflet could be explained by numerous zoospores having been released on the leaflet. Alternatively, zoospores could have already been released in the soil and have actively swum onto the leaflets touching the soil, or they could have been splashed onto the leaflets by rain.

In Lammi, the first symptoms were discovered on the stems of three plants. Tuber-borne inoculum was excluded since no late blight symptoms were observed on mother tubers, and the tubers did not contain detectable levels of $P$. infestans DNA. It is also very unlikely that these stem infections could have been related to an air-borne inoculum. Oospores may have stuck to the stem bases between the petiole and the stem when the plant was emerging, or oospores or zoospores were splashed onto leaf bases by rain. Thus the stem symptoms originated most likely from oospores.

It is confusing that we did not observe lesions on stem bases, which are typical for oospore-derived infections in Mexico and India (FernándezPavia et al. 2004, Singh et al. 2004). Perhaps the soil temperature during the early stage of potato development is too low in Finland, usually around $10^{\circ} \mathrm{C}$, limiting or reducing oospore germination. Later on, an underground stem may be too well protected against infections. In our inoculation tests, lower stem parts of tuber bearing plants were immune against $P$. infestans, but the plant tops were susceptible (data not shown).

\section{Mating type ratio}

In theory, oospores originating from different parents produce progeny possessing both mating types in a ratio of approximately $1: 1$, but ratios of even 1:2 have been reported (Gallegly 1968, Judelson et al. 1995). The reason for the deviation in the mating type ratio is unknown.

In our study, single-lesion isolates collected from initial foci and from the bioassay included both mating types on every occasion. The presence of both mating types explains the abundant forma- 
Lehtinen, A. \& Hannukkala, A. Oospore-derived potato late blight

tion of oospores in primary infected leaflets. In contrast, only one mating type was detected in $37 \%$ of the assumed air-borne epidemics. The frequency of the dominating mating type was at least $80 \%$ in three quarters of the epidemics. Thus, mating type frequencies in air-borne and suspected oospore-derived populations clearly differ of each other, latter being closer to a ratio of 1:1.

\section{Oospore occurrence in soil}

It was assumed that soil collected from suspected oospore-derived foci would be able to cause infections in bioassay too. However, the only infectious soils were collected from Jokioinen and Joroinen, where potatoes had been grown in monoculture without fungicide applications for the last decade. Infections in bioassay were obviously a consequence of the long history of severe epidemics on these fields, which enabled the accumulation of oospores in the soil. Other soil samples from fields with conventional chemical blight control were not infectious in the bioassay. This, together with the probably patchy occurrence of oospores in the soil, suggests that the accuracy of the bioassay and sampling scheme was not sensitive enough to detect an oospore inoculum capable of causing infections.

According to our data, it can be concluded that a suspected oospore-derived blight focus is most likely to be oospore-derived if 1) late blight has observed in the field in at least one of the four previous years (Turkensteen et al. 2000), 2) a focus appears before a secondary spread of late blight has been observed in the area, 3) primary lesions are on leaf edges touching the soil or if infected leaves show mosaic-like symptoms, 4) both mating types or oospores occur in the focus (Gallegly 1968, Drenth et al. 1995, Judelson et al. 1995), and 5) soil collected from the focus can infect potato leaflets in the bioassay (Drenth et al. 1995). However, a lack of infections in the bioassay does not necessarily rule out oospores, as the resolution of the baiting assay can be rather poor.

\section{Oospore influence on blight epidemics}

It is reasonable to expect that the emergence of a new source of inoculum in the form of oospores will have an influence on late blight epidemics. This is particularly true in Finland, where potatoes are grown in continuous monoculture or in crop sequences of 3-4 consecutive years of potatoes with a one-year cereal break. In addition, the cold northern climate is less favourable to the survival of asexual forms of primary inoculum than for example in the Netherlands, where overwintering tubers have been shown to provide the main source of primary inoculum (Zwankhuizen et al. 2000). Not surprisingly, Finnish farmers have experienced that the control of late blight is now more difficult, and sales of fungicides against potato late blight have as a consequence increased 3-4-fold since the 1980s (Hannukkala et al. 2003). However, the roles of the observed change in the blight population (Fry and Goodwin 1997, Flier and Turkensteen 1999) and of a possible shift towards a weather pattern more conducive to an early start of late blight epidemics cannot be excluded.

Further studies are necessary to evaluate the relative importance of oospore-derived inoculum as a source of primary infections in Nordic countries. In addition, the longevity of the oospores and their impact on potato monoculture needs to be assessed. It is essential to understand the weather conditions conducive to oospore-derived epidemics in order to improve existing decision support systems. A more accurate timing of the first fungicide application may be an important step in improving blight control in Finland.

Acknowledgements. We would like to thank the Finnish Ministry of Agriculture and Forestry and the Finnish Cultural Foundation for providing financial support for the study. We are grateful to Dr Terhi Rantanen for performing the PCR-diagnostics during the study, Ms Mari Helminen, Ms Marjo Segerstedt, Ms Senja Tuominen, Ms Tuija Vihervirta, and Ms Tuula Viljanen for their technical assistance in the course of the study, as well as to Ms Anne Rahkonen, Ms Elina Virtanen, Ms Sirkku Koskela, and Ms Paula Ilola for providing the soil samples from the fields in different parts of Finland. We also thank Prof. Aarne Kurppa and two anonymous referees for their critical reading of the manuscript and valuable suggestions. 


\section{References}

Andersson, B., Sandström, M. \& Strömberg, A. 1998. Indications of soil borne inoculum of Phytophthora infestans. Potato Research 41: 305-310.

Andrivon, D. 1995. Biology, ecology, and epidemiology of the potato late blight pathogen Phytophthora infestans in soil. Phytopathology 85: 1053-1056.

Drenth, A., Janssen, E.M. \& Govers, F. 1995. Formation and survival of oospores of Phytophthora infestans under natural conditions. Plant Pathology 44: 86-94.

Erwin, D.C. \& Ribeiro, O.K. 1996. Phytophthora diseases worldwide. 1st ed. St. Paul, Minnesota, American Phytopathological Society, APS Press. 562 p.

Fay, J.C. \& Fry, W.E. 1997. Effects of hot and cold temperatures on the survival of oospores produced by United States strains of Phytophthora infestans. American Potato Journal 74: 315-323.

Fernández-Pavia, S.P., Grunwald, N.J., Diaz-Valasis, M., Cadena-Hinojosa, M. \& Fry, W.E. 2004. Soilborne oospores of Phytophthora infestans in Central Mexico survive winter fallow and infect potato in the field. Plant Disease 88: 29-33.

Fernández-Pavia, S.P., Grûnwald, N.J. \& Fry, W.E. 2001. Infectivity and formation of oospores of Phytophthora infestans in the Toluca valley, Mexico. Phytopathology 91: S28.

Flier, W.G. \& Turkensteen, L.J. 1999. Foliar aggressiveness of Phytophthora infestans in three potato growing regions in the Netherlands. European Journal of Plant Pathology 105: 381-388.

Fry, W.E. \& Goodwin, S.B. 1997. Resurgence of the Irish potato famine fungus. BioScience 47: 363-371.

Gallegly, M.E. 1968. Genetics of pathogenicity of Phytophthora infestans. Annual Review of Phytopathology 6: 375-396.

Gallegly, M.E. \& Galindo, J. 1958. Mating types and oospores of Phytophthora infestans in nature in Mexico. Phytopathology 48: 274-277.

Hannukkala, A., Lehtinen, A. \& Rahkonen, A. 2003. Observed changes in blight epidemics and their consequences for blight control during the latest decade in Finland. In: Schepers, H.T.A.M \& Westerdijk, K. (eds.). Proceedings of the seventh workshop of an European network for development of an integrated control strategy of potato late blight. Poznan, Poland. PPO Special Report No 9. p. 67-72.

Hermansen, A., Hannukkala, A., Nærstad, R.H. \& Brurberg, M.B. 2000. Variation in populations of Phytophthora infestans in Finland and Norway: mating type, metal- axyl resistance and virulence phenotype. Plant Pathology 49: 11-22.

Hohl, H.R. \& Iselin, K. 1984. Strains of Phytophthora infestans from Switzerland with A2 mating type behaviour. Transactions of the British Mycological Society 83: 529-530.

Judelson, H.S., Spielman, L.J. \& Shattoc, R.C. 1995. Genetic mapping and non-Mendelian segregation of mating type loci in the oomycete, Phytophthora infestans. Genetics 141: 503-512.

Judelson, H.S. \& Tooley, P.W. 2000. Enhanced polymerase chain reaction methods for detecting and quantifying Phytophthora infestans in plants. Phytopathology 90: 1112-1119.

Mäkelä, K. 1966. Factors influencing the epidemics of Phytophthora infestans (Mont.) De Bary in Finland. Acta Acralia Fennica 104: 1-100.

Medina, M.V. \& Platt, H.W. 1999. Viability of oospores of Phytophthora infestans under field conditions in northeastern North America. Canadian Journal of Plant Pathology 21: 137-143.

Seppänen, E. 1971. Influence of weather conditions and late blight on the yields of potatoes in Finland 1931-62. Annales Agriculturae Fenniae 10: 69-108.

Singh, B.P., Gupta, J., Roy, S. \& Rana, D.K. 2004. Production of Phytophthora infestans oospores in Planta and inoculan potential of in vitro produced oospores under temparate highlands and sub-tropical plains if India. Annals of Applied Biology 144: 363-370.

Smoot, J.J., Gough, F.J., Lamey, H.A., Eichenmuller, J.J. \& Gallegly, M.E. 1958. Production and germination of oospores of Phytophthora infestans. Phytopathology 48: $165-171$.

Strömberg, A., Persson, L. \& Wikström, M. 1999. Infection of potatoes by oospores of Phytophthora infestans in soil. Plant Disease 83: 876.

Turkensteen, L.J., Flier, W.G., Wanningen, R. \& Mulder, A. 2000. Production, survival and infectivity of oospores of Phytophthora infestans. Plant Pathology 49: 688696.

Zwankhuizen, M.J., Govers, F. \& Zadoks, J.C. 2000. Inoculum sources and genotypic diversity of Phytophthora infestans in Southern Flevoland, the Netherlands. European Journal of Plant Pathology 106: 667-680.

Zwankhuizen, M.J. \& Zadoks, J.C. 2002. Phytophthora infestans's 10-year truce with Holland: a long-term analysis of potato late-blight epidemics in the Netherlands. Plant Pathology 51: 413-423. 


\title{
SELOSTUS
}

\section{Perunaruton munaitiöt maassa ovat uusi merkittävä epidemian alkulähde Suomessa}

\author{
Ari Lehtinen ja Asko Hannukkala \\ MTT (Maa- ja elintarviketalouden tutkimuskeskus)
}

Perunarutto on maailmanlaajuisesti yksi perunan tuhoisimmista taudeista. Sen aiheuttaja on munasieniin kuuluva Phytophthora infestans (Mont.) de Bary, jolla on kaksi pariutumistyyppiä," sukupuolta", A1 ja A2. Esiintyessään toistensa läheisyydessä eri pariutumistyypin ruttokannat pystyvät lisääntymään suvullisesti ja muodostamaan munaitiöitä. A2-tyyppiä esiintyi vain Meksikossa 1980-luvun alkuun asti. Molemmat pariutumistyypit omaava uusi ruttopopulaatio levisi Eurooppaan 1980-luvulla ja syrjäytti nopeasti vanhan populaation. Suomessa uuden ruttopopulaation edustajia havaittiin ensimmäisen kerran 1992. Koska tätä vanhempia ruttokantoja ei ole Suomesta saatavilla, uuden populaation tarkkaa leviämisajankohtaa ei ole mahdollista selvittää. Vanhan populaation edustajia ei kartoitusten aikana ole Suomesta havaittu.

Uusi ruttopopulaatio tuottaa Euroopassa suvullisen lisääntymisen seurauksena munaitiöitä. Munaitiöt ovat paksuseinäisiä ja kestäviä itiöitä, jotka säilyvät maassa jopa 4 vuotta infektiokykyisinä. Viitteitä munaitiöiden aiheuttamista epidemioista on raportoitu Euroopassa Hollannista ja Ruotsista. Tämän tutkimuksen tavoitteena oli selvittää, esiintyykö Suomessa munaitiöistä alkunsa saaneita perunaruttoepidemioita. Kirjallisuuden perusteella munaitiöistä alkava ruttoepidemia määriteltiin seuraavasti:

1. Ruttopesäkkeitä ilmaantuu perunakasvustoon aikaisin kesällä lohkolla, jolla on yhtenä neljästä viime vuodesta ollut ruttoinen perunakasvusto.

2. Ensioireet ilmaantuvat lähellä maata oleviin tai sitä koskettaviin lehtiin tai varsiin.

3. Ruttopesäkkeessä esiintyy molempia pariutumistyyppejä edustavia kantoja ruttoepidemian alussa, koska jälkeläisillä on suunnilleen yhtä suuri todennäköisyys periä A1- tai A2-pariutumistyyppi vanhemmiltaan.
4. Oletetuista maatartuntapesäkkeistä otettu multanäyte tartuttaa perunan lehdet tarkoitukseen kehitetyssä pyydyskasvitestissä.

Maalähtöisiä ruttoepidemioita kartoitettiin 2000 2002 etsimällä aikaisin ilmaantuneita ruttopesäkkeitä tarkempia tutkimuksia varten. Ensisijaisesti toimittiin MTT:n koekentillä Jokioisissa, Perunantutkimuslaitoksella Lammilla sekä noin 30 varhaisperunan- ja palstaviljelijän pelloilla, joilla otaksuttiin 1. ehdon toteutuvan.

Yhteensä 20 epäiltyä maatartuntapesäkettä tutkittiin 2000-2002. Näissä ensimmäiset rutto-oireet ilmaantuivat alalehtiin. Normaalista poiketen alalehdet olivat yleensä ruton kirjavoittamia lukuisien tartuntojen seurauksena, ja ne tuhoutuivat muutamassa päivässä. Lähes kaikissa monilaikkuisissa lehdyköissä syntyi inkuboinnin jälkeen runsaasti munaitiöitä, mikä osoitti molempien pariutumistyyppien läsnäolon pesäkkeessä. Suoraan pelloilta kerätyistä varsista löytyi myös munaitiöitä Jokioisilta ja Nummi-Pusulasta. Koska Jokioisilta keväällä kerätyt multanäytteet tartuttivat perunanlehtiä kasvihuoneessa tehdyssä pyydyskasvitestissä, pystyvät munaitiöt säilymään Suomessa talven yli maassa.

Munaitiöiden muodostuminen ja säilyminen maassa talven yli osoittaa, että Suomessa on edellytykset maatartunnalle. Ensimmäisten ruttolaikkujen ilmaantuminen lehdykän maata koskettavaan reunaan tai lukuisien pienten laikkujen ilmaantuminen alalehteen on myös helpointa selittää maatartunnalla. Vielä ei kuitenkaan tiedetä, miten yleisiä maalähtöiset epidemiat ovat. Maatartunnan hallitsemiseksi pitäisi edelleen selvittää, minkälaiset kosteus- ja lämpöolot ovat kriittisiä tekijöitä infektion etenemiselle, ja miten maatartunnan riskiä voitaisiin nykyistä paremmin ennakoida. 